ORIGINS OF THE MEDIEVAL WORLD 



\title{
ORIGINS OF THE MEDIEVAL WORLD
}

\author{
William Carroll Bark
}




\section{Stanford University Press}

Stanford, California

(C) 1958 by the Board of Trustees of the

Leland Stanford Junior University

Printed in the United States of America

Cloth ISBN 0-8047-0513-5

Paper ISBN 0-8047-0514-3

Original printing 1958

Last figure below indicates year of this printing:

$\begin{array}{lll}98 & 97 & 96\end{array}$ 
M. L. W. LAISTNER

MAGISTRO ET AMICO 
